\title{
Physico-Chemical Properties of Coarse Rice Cultivars Grown in Different Areas of Punjab and Sindh, Pakistan
}

\author{
Ghazala Kausar* \\ Faculty of Food, Nutrition and Home Sciences, National Institute of Food Science and Technology, University \\ of Agriculture Faisalabad, Pakistan \\ Mian Kamran Sharif \\ Faculty of Food, Nutrition and Home Sciences, National Institute of Food Science and Technology, University \\ of Agriculture Faisalabad, Pakistan
}

\begin{abstract}
Rice (Oryza sativa L) is the second largest important cultivated cereal. Rice being an invaluable alternative source of carbohydrate being easily digestible and has rare allergic reactions. Coarse rice is known for its puffing characters and used in many puffed or extruded products. Puffed rice is also very popular in other countries as breakfast cereal and essential component of cereal based snacks. Five coarse rice varieties namely IRRI-9, IRRI6, KSK-133, KSK-434 and Shadab were milled to obtain brown rice and white rice. Proximate composition revealed that protein, ash, fat and fiber were significantly higher in brown rice than white rice. The length $(7.67 \mathrm{~mm})$ and width $(2.35 \mathrm{~mm})$ was higher in KSK-434 whereas higher thickness $(2.05 \mathrm{~mm})$ was observed in KSK-133. The highest bulk density $\left(0.93 \mathrm{~g} / \mathrm{cm}^{3}\right)$ was observed in IRRI-6 whereas IRRI-9 shows lowest $\left(0.88 \mathrm{~g} / \mathrm{cm}^{3}\right)$ values. Thousand kernel weight (TKW) was ranged from 15.83 to $20.02 \mathrm{~g}$ and 18.28 to $22.84 \mathrm{~g}$ among the milling fractions of white and brown rice, respectively. Thousand kernel weight was found to be higher in KSK-434 followed by Shadab, KSK-133 and the lowest values were observed in IRRI-9. Moisture, ash, fiber, protein, fat and NFE (nitrogen free extract) contents ranged from 9.23 to $12.26 \mathrm{~g} / 100 \mathrm{~g}, 0.67$ to $3.81 \mathrm{~g} / 100 \mathrm{~g}, 0.98$ to $4.21 \mathrm{~g} / 100 \mathrm{~g}$ and 6.04 to $8.98 \mathrm{~g} / 100 \mathrm{~g}, 1.23$ to $5.45 \mathrm{~g} / 100 \mathrm{~g}$ and 65.87 to $80.28 \mathrm{~g} / 100 \mathrm{~g}$ respectively among different milling fractions. The amylose contents for IRRI-9, IRRI-6, KSK-133, KSK-434 and Shadab ranged from 27.07 to $28.25 \%, 27.55$ to $29.78 \%, 26.48$ to $27.96 \%, 26.80$ to $28.98 \%$ and 29.03 to $30.88 \%$ respectively among different varieties. With respect to amylose, length, thousand kernel weight and bulk density, higher values were observed in KSK-434 and Shadab. Shadab shows best values (higher amylose and lower protein) for extrusion and puffing purposes. Brown rice showed higher nutritional values with respect to protein, fiber, ash (minerals) and fat.
\end{abstract}

Keywords: Brown rice, White rice, Amylose, Fractions, Coarse rice

DOI: $10.7176 / \mathrm{JBAH} / 9-5-02$

Publication date:March $31^{\text {st }} 2019$

\section{Introduction}

Rice (Oryza sativa L.) is one of the most important food crop feeding more than 2 billion people in Asia. Rice is the staple food of about 50\% world population, regardless of lower micronutrient contents (Bhattacharya, 2004). The major rice producing countries of the world are China, Bangladesh, India, Vietnam and Indonesia. It is no longer a luxury food but has become a cereal which constitutes a main source of the calories for rural and urban population (Sasaki and Burr, 2000). Approximately 80\% of daily calorie intake of three billion people is provided by rice. Paddy production in the world amounts to 718.35 million metric tons (MMT), out of which more than $90 \%$ production is in Asia (Kumar and Prasad, 2013). Pakistan produces about 6 million tonnes rice each year and together with rest of South Asia, supplying 25\% paddy rice of the world (Prasad et al., 2010). According to Pakistan Economic Survey 2016-17, rice was cultivated on 2724 thousand hectares and production was 6849 thousand tonnes. It contributes $0.6 \%$ of the GDP and $3.0 \%$ value added in agriculture. Both fine $(40 \%)$ and coarse cultivars $(60 \%)$ are mainly grown in Punjab and Sindh provinces. Among the major rice varieties, Super Basmati, Super Kernal, Kainat, Basmati 515, Pk-386, IRRI-6, IRRI-9, KSK-133, KSK-434, KS-282, Shadab and Shua-92 are cultivated to cater the local needs as well as for export especially to the Middle East.

Rice, being rich in carbohydrates, contributes to about $60-70 \%$ of the daily energy needs and approximately $15 \%$ protein requirements of the masses. Seed is fully enveloped by the hull that is removed during milling and yielding brown rice. In second stage of milling, outer brown layer called rice bran is removed to produce white rice. Rice bran is composed of rice germ and several sub layers. Rice bran contains over $60 \%$ of nutrients found in each seed of rice. Rice is source of minerals like magnesium, calcium and phosphorus but nutritionally low in protein and micronutrients including iron, zinc, manganese, cobalt, etc. (Oko and Ugwa, 2011). Today, with advance technology, rice has emerged as an efficient vehicle for fortification. Pakistan produces about 6-7 million tonnes rice each year and together with rest of South Asia, supplying 25\% paddy rice of the world (Prasad et al., 2010). Rice has been considered the best starchy staple food among all cereal crops that has high biological value, digestibility and protein efficiency ratio due to presence of higher lysine concentration $(\sim 4 \%)$. Rice starch is 
digested rapidly as compared with starch of other foods like sweet potato, noodles etc. (Frei and Becker, 2003). Rice is extensively used in convenience foods for example puffed, multigrain flakes, breakfast cereals, extruded and popped rice. Cooking and eating properties are generally determined by the characteristics of the rice starch that makes upto $90 \%$ of milled rice grain. The consumers are concerned to purchase high quality rice. Other important properties such as amylose content, volume expansion ratio, water absorption ratio and final starch gelatinization temperature also determine cooking and eating qualities of rice (Shabbir et al., 2008). Objective of this study was to characterize popular coarse rice cultivars (IRRI-9, IRRI-6, KSK-133, KSK-434 and Shadab) based on their physico-chemical properties.

\section{Materials and Methods}

\subsection{Sample Collection}

Five Pakistani popular coarse rice cultivars (IRRI-9, IRRI-6, KSK-133, KSK-434 and Shadab) were obtained from Rice Research Institute, Kala Shah Kaku, Punjab and Rice Research Institute Dokri, Sindh.

\subsection{Milling of Paddy Samples}

After drying, paddy was dehulled into brown rice using husker (Satake Rice Husker, Tokyo, Japan). Subsequently, brown rice was converted into white rice and co-products through rice polisher (Satake Rice Polisher, Tokyo, Japan). Furthermore, brown and white rice samples were milled through UDY Cyclone Mill (Cyclotec Sample Mill, Tecator, Sweden) to obtain flour for further analysis.

\subsection{Physico-chemical Analysis}

The physical characteristics including grain size (length, width and thickness) was measured by using micrometer (Vernier calliper) and thousand kernel weight (TKW) was recorded in $\mathrm{g} / 1000$ kernel by counting grains and weighing on an electric balance. Bulk density was determined by the ratio of the mass to a given volume (Park, 2001). The rice samples of each cultivar were analyzed individually in triplicate for moisture (Method No. 44-15 A), ash (Method 08-01), crude fiber (Method 32-10), crude protein (AACC Method 46-10), crude fat (Method 3010) and NFE (nitrogen free extract) following respective procedures as described in AACC (2000). The amylose content in each rice sample was determined by using Spectrophotometer according to modified method of Juliano (1971) and Hoke et al. (2005).

\subsection{Statistical Analysis}

The data obtained for each parameter was analyzed statistically to determine the level of significance as described by Steel et al. (1997). Data was measured in triplicate and subjected to analysis of variance (ANOVA). Completely randomized design $(\mathrm{CRD})$ was applied on the data to assess the significance level and differences $(\mathrm{p} \leq 0.05)$ among the means of treatments showing significant differences.

\section{Results and Discussions}

\subsection{Physical Characteristics}

Mean squares for physical characteristics of rice varieties, rice fractions and their interaction showed significant differences $(\mathrm{p} \leq 0.05)$ with respect to grain size (length, width and thickness), thousand kernel weight (TKW) and bulk density (Table 1). The highest length was observed in brown fraction as compared to white rice. Among the different cultivars, KSK-434 showed highest length $(7.67 \pm 0.03 \mathrm{~mm})$ and width $(2.35 \pm 0.04 \mathrm{~mm})$ whereas the lowest length $(6.62 \pm 0.04 \mathrm{~mm})$ and width $(1.76 \pm 0.01 \mathrm{~mm})$ values were noted in IRRI-9 and IRRI-6 respectively (Table 2). The lowest thickness $(1.58 \pm 0.05 \mathrm{~mm})$ was noted in Shadab. In a study, comparative study of physicochemical properties of mutant rice varieties cultivated in Sindh, selected quality attribute of rice cultivars revealed length ranged from 6.95 to $7.5 \mathrm{~mm}$ (Ansari et al., 2013). Similarly, in another study, cooking and physicochemical properties of five rice varieties produced in Ohaukwu local government area, length and width ranged from 5.95$7.53 \mathrm{~mm}$ and $2.17-2.87 \mathrm{~mm}$ respectively (Chukwuemeka et al., 2015). Likewise, in another study, KSK 133-a high yielding, stiff stemmed and extra long grain coarse rice variety, length $(7.07 \mathrm{~mm})$, width $(2.11 \mathrm{~mm})$ and thickness range (1.54-1.79mm) are reported for KSK-133 (Akhtar et al., 2007). In a study, some physical properties of rice seed (Oryza sativa L), selected quality attribute of rice cultivars revealed thickness in the range of $2.53-2.75 \mathrm{~mm}$ (Jouki and Khazaei, 2012).

The brown fraction showed higher thousand kernel weight (TKW) whereas high bulk density was observed in white fraction. Among the different cultivars, KSK-434 showed highest thousand kernel weight $(22.84 \pm 0.15 \mathrm{~g})$ followed by Shadab $(21.92 \pm 0.16 \mathrm{~g})$ and KSK-133 $(20.77 \pm 0.18 \mathrm{~g})$ whereas the lowest value $(15.83 \pm 0.04 \mathrm{~g})$ was noted in IRRI-9 (Table 2). In a study, comparative study of physicochemical properties of mutant rice varieties cultivated in Sindh, selected quality attribute of rice cultivars revealed TKW ranged from 1.73-21.1g (Ansari et al., 2013). IRRI-6 showed highest bulk density $\left(0.93 \pm 0.01 \mathrm{~g} / \mathrm{cm}^{3}\right)$ whereas the lowest value $\left(0.90 \pm 0.01 \mathrm{~g} / \mathrm{cm}^{3}\right)$ was noted in KSK-133 (Table 2). In a study, effect of milling variables on the degree of milling of nonparboiled and 
parboiled rice, selected quality attribute of rice cultivars revealed bulk density ranged from $0.71-0.83 \mathrm{~g} / \mathrm{cm}^{3}$ (Singh et al., 2002). The same parameter in another study, effect of parboiling on physico-chemical and cooking attributes of different rice cultivars, bulk density ranged from $0.72-2-0.82 \mathrm{~g} / \mathrm{cm}^{3}$ in brown rice and $0.74-0.82 \mathrm{~g} / \mathrm{cm}^{3}$ for white rice (Saeed et al., 2011).

\subsection{Chemical characteristics}

\subsubsection{Proximate composition}

Mean squares for proximate composition among different rice varieties, rice fractions and their interaction showed significant differences $(\mathrm{p} \leq 0.05)$ with respect to moisture, ash, crude fiber, crude protein, crude fat and nitrogen free extract (Table 3 ).

The moisture content varied from 9.23 to $12.26 \mathrm{~g} / 100 \mathrm{~g}$ among rice varieties (Table 2 ). The highest moisture content was observed in brown fraction as compared to white rice. Among the different cultivars, IRRI-6 showed highest moisture $(12.26 \pm 0.01 \mathrm{~g} / 100 \mathrm{~g})$, KSK-434 highest ash $(3.81 \pm 0.05 \mathrm{~g} / 100 \mathrm{~g})$, IRRI-9 highest crude fiber contents $(4.21 \pm 0.05 \mathrm{~g} / 100 \mathrm{~g})$ and KSK-434 showed highest crude protein contents $(8.98 \pm 0.01 \mathrm{~g} / 100 \mathrm{~g})$. Means for crude fat contents showed values ranged from 1.23-4.02g/100g. Among the different cultivars, IRRI-9 showed highest crude fat contents $(5.45 \pm 0.05 \mathrm{~g} / 100 \mathrm{~g})$ followed by KSK-434 (4.02 $\pm 0.01 \mathrm{~g} / 100 \mathrm{~g})$ and IRRI-6 $(3.78 \pm 0.01 \mathrm{~g} / 100 \mathrm{~g})$ whereas the lowest value $(1.23 \pm 0.05 \mathrm{~g} / 100 \mathrm{~g})$ was noted in KSK-133 (Table 4). Milled rice crude fat is significantly lower than brown rice fraction due to the removal of bran. The highest NFE content $(80.28 \mathrm{~g} / 100 \mathrm{~g})$ was observed in white fraction as compared to brown rice $(65.87 \mathrm{~g} / 100 \mathrm{~g})$.

The variation in the proximate composition of rice is due to the difference of variety (genetic makeup) and climatic change and differences in different milling fractions was due to degree of severity during milling for the separation of bran. In a study, mineral composition of different rice varieties and their milling fractions, selected quality attribute of rice cultivars revealed moisture, ash, crude fiber and NFE content ranged from 9.19 to $11.10 \mathrm{~g} / 100 \mathrm{~g}, 0.54$ to $6.04 \mathrm{~g} / 100 \mathrm{~g}, 2.17$ to $2.57 \mathrm{~g} / 100 \mathrm{~g}$ and 67.75 to $71.43 \mathrm{~g} / 100 \mathrm{~g}$ respectively (Anjum et al., 2007). Likewise, in another study, effect of parboiling on physico-chemical and cooking attributes of different rice cultivars, moisture content ranged from 9.39-12.84g/100g for white rice and $12.10-13.50 \mathrm{~g} / 100 \mathrm{~g}$ for brown rice and crude protein content ranged from $6.82-10.05 \mathrm{~g} / 100 \mathrm{~g}$ in brown rice fraction and $6.08-9.83 \mathrm{~g} / 100 \mathrm{~g}$ in white rice fraction (Saeed et al., 2011). Means for crude protein contents showed values ranged from 7.08-8.45\%. Protein negatively effects puffiness of coarse rice varieties containing high amylose contents. In a study, comparative study of nutrient composition of commercial brown, parboiled and milled rice from Brazil, selected quality attribute of rice cultivars revealed crude protein and fat content $9.70 \mathrm{~g} / 100 \mathrm{~g}$ and $1.29 \mathrm{~g} / 100 \mathrm{~g}$ for brown rice and $6.85 \mathrm{~g} / 100 \mathrm{~g}$ and $0.66 \mathrm{~g} / 100 \mathrm{~g}$ for white rice respectively (Heinemann et al., 2005).

\subsubsection{Amylose Content (\%)}

Mean squares for amylose contents of rice varieties, rice fractions and interaction of rice varieties and fractions revealed significant differences $(\mathrm{p} \leq 0.05)$ with respect to amylose content (Table 5). Means for amylose content showed values ranged from 27.22 to $29.95 \%$. The amylose content was higher $(29.17 \%)$ in white fraction as compared to brown fraction (27.38\%). Among the different cultivars, Shadab showed the highest amylose (30.88\%) followed by IRRI-6 (29.78\%) and KSK-133 (28.98\%) whereas the lowest value (26.48\%) was noted in KSK-434 (Table 6). The variation in the amylose content of brown and white rice of some cultivar was might be due to slight differences in degree of milling and presence of bran on brown rice fraction which contain less amylose as compared to endosperm, whereas differences among the varieties were due to genetic variations. In a study, Pakistani rice cultivars showed amylose content ranged from 21.6 to $30.7 \%$ (Khurram et al., 2007). Likewise, in another study, cooking and eating characteristics of Rice (Oryza sativa L.) were investigated. The amylose content was ranged from $22.90 \%$ to $26.19 \%$ in brown rice and $24.14 \%$ to $25.31 \%$ in white rice (Asghar et al., 2012). The amylose content of rice plays an important role in its puffing characteristics. Amylose is composed of linear chain of glucose molecules which align themselves in the shear fields and thus are difficult to pull apart during the extrusion process (Moraru and Kokini, 2003). Since high-amylose content rice varieties are hard to shear, there is a greater chance that pressure will build up during the thermal treatment. This perhaps results in a sudden expansion of the endosperm, making it a highly preferred product as compared to their low amylose content counterparts. It has been observed that highly packed starch molecules have a better ability to expand compared to the loosely packed chalky grains (Kamaraddi et al., 2015).

\section{Conclusion}

In conclusion, brown rice of all coarse rice cultivars has better nutritional quality as compared with their white rice due to significantly more available nutrients in bran portion. Physiochemical properties are of major importance while developing a variety of rice. These properties include grain size (length, width and thickness), grain weight, protein and amylose contents. Weight of grain gives information about the size and density of grain. The rice grains density effects the cooking quality. So, grain weight should be uniform for netter cooking quality. It is concluded from the present study that Shadab and KSK-434 should get more attention by the rice breeders as these 
have better physiochemical characteristics (more TKW, length and amylose). It is required to characterize the rice cultivars, so that the knowledge can be used for rice export policies and for developing breeding strategies to increase yield keeping intact their physiochemical characteristic. Timely characterization of rice cultivars, will enhance the export of rice. Government should make polices to export more good quality brown rice in those European countries where the people like brown rice due to its more nutritional value as compared to white.

\section{References}

AACC (The American Association of Cereal Chemists). (2000). Approved Methods of American Assoc. Cereal Chem. Inc., St. Paul. Minnesota, USA

Akhter, M. et al. (2007). KSK 133-a high yielding, stiff stemmed and extra long grain coarse rice variety. J. Anim. Plan. Sci., 17, 1-6

Ansari, I.T. et al. (2013). Comparative study of physicochemical properties of mutant rice varieties cultivated in Sindh. Sindh Univ. Res. J. Sci. Ser., 45, 17-20

Asghar, S. et al. (2012). Cooking and eating characteristics of Rice (Oryza sativa L.) - A Review. Pak. J. Food Sci., 22, 128-132

Bhattacharya, K. et al. (2004). Parboiling of rice. In: Rice Chemistry and Technology, $3^{\text {rd }}$ Ed. American Association of Cereal Chemists, Inc., St. Paul, Minnesota, USA

Chukwuemeka, A.I. et al. (2015). Cooking and physicochemical properties of five rice varieties produced in Ohaukwu local government area. Eur. J. Food Sci. Technol., 3, 1-10

GOP (Government of Pakistan). (2015). Economic Survey of Pakistan 2014-2015. Economic Affairs Division, Government of Pakistan. Islamabad.

Heinemann, R. et al. (2005). Comparative study of nutrient composition of commercial brown, parboiled and milled rice from Brazil. J. Food Comp. Ana., 18, 287-296

Hoke, K. et al. (2005). Optimum conditions of rice puffing - Review. Czech J. Food Sci., 23, 1-11

Jouki, M., \& Khazaei, N. (2012). Some physical properties of rice seed (Oryza sativa). Res. J. Appl. Sci. Eng. Technol., 4, 1846-1849

Juliano, B.O. (1971). A simplified assay for milled rice amylose. Cereal Sci. Today, 16, 334-340

Khurram, B. et al. (2007). Indica rice varietal development in Pakistan: an overview. Paddy Water Environ., 5, $73-81$

Kumar, S. \& Prasad, K. (2013). Effect of paddy parboiling and rice puffing on physical, optical and aerodynamic characteristics. Int. J. Agric. Food Sci. Technol., 4, 765-770

Prasad, K. et al. (2010). Rice based functional cookies for celiac: Studies on its formulation. Lambert Academic Publishing, Saarbrucken, Germany. pp. 1-128

Saeed, F. et al. (2011). Effect of parboiling on physico-chemical and cooking attributes of different rice cultivars. Int. J. Food Saf., 13, 237-245

Sasaki, T. \& Burr, B. (2000). International rice genome sequence project: the effort to complete the sequence of rice genome. Current Opinion in Plant Biology, 3, 138-144

Shabbir, M.A. et al. (2008). Mineral and pasting characterization of Indica rice varieties with different milling fractions. Int. J. Agri. Biol., 10, 556-560

Frei, M. \& Becker, K. (2003). Studies on the in vitro starch digestibility and glycemic index of six different indigenous rice cultivars from the Philippines. J. Food Chem., 83, 395-400

Singh, H.G. et al. (2002). Effect of milling variables on the degree of milling of unparboiled and parboiled rice. Int. J. Food Prop., 5, 193-204

Steel, R.G.D. et al. (1997). Principles and Procedures of Statistics: A Biometrical Approach, $3^{\text {rd }}$ Ed. McGraw Hill Book Co. Inc., New York, USA

Oko, A.O. \& Ugwu, S.I. (2011). The proximate and mineral compositions of five major rice varieties in Abakaliki, South-Eastern Nigeria. Inter. J. Plant Physio. Biochem., 3, 25-27

Table 1. Mean Squares for Physical Characteristics of brown and white fractions of different rice cultivars

\begin{tabular}{lllllll}
\hline Source of Variations & df & Length & Width & Thickness & TKW & Bulk density \\
\hline Rice Varieties (V) & 4 & $0.4876^{* *}$ & $0.1867^{* *}$ & $0.133^{* *}$ & $19.65^{* *}$ & $0.0017^{* *}$ \\
Rice Fractions (F) & 1 & $0.8003^{* *}$ & $0.1051^{* *}$ & $0.127^{* *}$ & $34.71^{* *}$ & $0.0007^{* *}$ \\
V*F & 4 & $0.0075^{*}$ & $0.005^{*}$ & $0.005^{*}$ & $0.401^{* *}$ & $0.0003^{* *}$ \\
Error & 80 & 0.00187 & 0.0012 & 0.0012 & 0.0214 & 0.00001 \\
Total & 89 & & & & & \\
\hline
\end{tabular}

Note: $* *=$ Highly Significant, $*=$ Significant at $\mathrm{P} \leq 0.05$ 
Table 2. Effect of rice cultivar on physical Characteristics of brown and white rice fractions of different rice cultivars

\begin{tabular}{|c|c|c|c|c|c|c|}
\hline Variety & Fraction & $\begin{array}{l}\text { Length } \\
(\mathrm{mm})\end{array}$ & $\begin{array}{l}\text { Width } \\
\text { (mm) }\end{array}$ & $\begin{array}{l}\text { Thickness } \\
\text { (mm) }\end{array}$ & $\begin{array}{l}\text { Bulk density } \\
\left(\mathrm{g} / \mathrm{cm}^{3)}\right.\end{array}$ & $\begin{array}{l}\text { TKW } \\
\text { (g) }\end{array}$ \\
\hline \multirow[t]{2}{*}{ IRRI-9 } & Brown & $7.18 \pm 0.02$ & $1.96 \pm 0.03$ & $1.70 \pm 0.04$ & $0.88 \pm 0.01$ & $18.28 \pm 0.03$ \\
\hline & White & $6.87 \pm 0.03$ & $1.76 \pm 0.01$ & $1.61 \pm 0.00$ & $0.88 \pm 0.05$ & $15.83 \pm 0.04$ \\
\hline \multirow[t]{2}{*}{ IRRI-6 } & Brown & $6.80 \pm 0.07$ & $2.18 \pm 0.05$ & $1.78 \pm 0.02$ & $0.90 \pm 0.02$ & $19.03 \pm 0.02$ \\
\hline & White & $6.62 \pm 0.04$ & $2.12 \pm 0.05$ & $1.56 \pm 0.04$ & $0.93 \pm 0.01$ & $17.53 \pm 0.17$ \\
\hline \multirow[t]{2}{*}{ KSK-434 } & Brown & $7.67 \pm 0.03$ & $2.35 \pm 0.04$ & $1.90 \pm 0.02$ & $0.90 \pm 0.02$ & $22.84 \pm 0.15$ \\
\hline & White & $7.25 \pm 0.05$ & $2.28 \pm 0.02$ & $1.79 \pm 0.02$ & $0.91 \pm 0.03$ & $20.02 \pm 0.07$ \\
\hline \multirow[t]{2}{*}{ KSK-133 } & Brown & $7.46 \pm 0.05$ & $2.29 \pm 0.03$ & $2.05 \pm 0.05$ & $0.89 \pm 0.03$ & $20.77 \pm 0.18$ \\
\hline & White & $7.16 \pm 0.04$ & $2.17 \pm 0.04$ & $1.89 \pm 0.04$ & $0.90 \pm 0.01$ & $18.96 \pm 0.18$ \\
\hline \multirow[t]{2}{*}{ Shadab } & Brown & $7.62 \pm 0.01$ & $2.10 \pm 0.05$ & $1.66 \pm 0.05$ & $0.92 \pm 0.01$ & $21.92 \pm 0.16$ \\
\hline & White & $7.18 \pm 0.02$ & $1.97 \pm 0.03$ & $1.58 \pm 0.05$ & $0.92 \pm 0.02$ & $19.75 \pm 0.22$ \\
\hline
\end{tabular}

Note: Values are presented as Means $\pm \mathrm{SD} ; \mathrm{n}=9$

Table 3. Mean squares for proximate composition of brown and white fractions of different rice cultivars

\begin{tabular}{llllllll}
\hline Source of Variations & df & Moisture & Ash & Fiber & Protein & Fat & NFE \\
\hline Rice Varieties (V) & 4 & $2.466^{* *}$ & $43.54^{* *}$ & $0.899^{* *}$ & $2.398^{* *}$ & $5.284^{* *}$ & $37.2^{* *}$ \\
Rice Fractions (F) & 1 & $10.54^{* *}$ & $16.66^{* *}$ & $34.56^{* *}$ & $17.05^{* *}$ & $22.23^{* *}$ & $486^{* *}$ \\
V*F & 4 & $0.545^{* *}$ & $0.151^{* *}$ & $0.117^{* *}$ & $0.240^{* *}$ & $0.109^{* *}$ & $0.99^{* *}$ \\
Error & 20 & 0.0003 & 0.0008 & 0.0001 & 0.0005 & 0.0007 & 0.003 \\
Total & 29 & & & & & & \\
\hline Note: $* *=$ Highly Significant at $\mathrm{P} \leq 0.05$ & & & & & &
\end{tabular}

Table 4. Effect of cultivar on proximate Composition $(\mathrm{g} / \mathbf{1 0 0 g})$ of brown and white rice fractions of different rice cultivars

\begin{tabular}{llllllll}
\hline Variety & Fraction & Moisture & Ash & Fiber & Protein & Fat & NFE \\
\hline IRRI-9 & Brown & $12.21 \pm 0.05$ & $3.75 \pm 0.05$ & $4.21 \pm 0.05$ & $8.49 \pm 0.02$ & $5.45 \pm 0.05$ & $65.87 \pm 0.01$ \\
& White & $11.33 \pm 0.05$ & $2.36 \pm 0.01$ & $1.63 \pm 0.02$ & $7.24 \pm 0.01$ & $3.51 \pm 0.05$ & $73.91 \pm 0.04$ \\
IRRI-6 & Brown & $12.26 \pm 0.01$ & $3.46 \pm 0.01$ & $3.77 \pm 0.05$ & $8.27 \pm 0.05$ & $3.78 \pm 0.01$ & $68.60 \pm 0.02$ \\
& White & $10.25 \pm 0.01$ & $1.86 \pm 0.05$ & $1.68 \pm 0.05$ & $6.73 \pm 0.06$ & $2.02 \pm 0.01$ & $76.63 \pm 0.07$ \\
KSK-434 & Brown & $11.26 \pm 0.01$ & $3.81 \pm 0.05$ & $3.21 \pm 0.05$ & $8.98 \pm 0.01$ & $4.02 \pm 0.01$ & $68.70 \pm 0.07$ \\
& White & $09.23 \pm 0.01$ & $1.88 \pm 0.01$ & $0.98 \pm 0.05$ & $7.92 \pm 0.01$ & $2.06 \pm 0.01$ & $77.92 \pm 0.02$ \\
KSK-133 & Brown & $11.03 \pm 0.02$ & $1.73 \pm 0.05$ & $3.06 \pm 0.05$ & $8.28 \pm 0.01$ & $2.53 \pm 0.07$ & $73.36 \pm 0.11$ \\
& White & $10.57 \pm 0.01$ & $0.67 \pm 0.01$ & $1.08 \pm 0.05$ & $6.16 \pm 0.01$ & $1.23 \pm 0.05$ & $80.28 \pm 0.05$ \\
Shadab & Brown & $12.09 \pm 0.02$ & $2.10 \pm 0.01$ & $3.58 \pm 0.01$ & $8.13 \pm 0.05$ & $3.57 \pm 0.05$ & $68.42 \pm 0.02$ \\
& White & $11.06 \pm 0.03$ & $1.16 \pm 0.01$ & $1.73 \pm 0.01$ & $6.04 \pm 0.01$ & $1.92 \pm 0.05$ & $76.47 \pm 0.30$ \\
\hline
\end{tabular}

Note: Values are presented as Means $\pm \mathrm{SD} ; \mathrm{n}=3$

Table 5. Mean squares for amylose content of brown and white fractions of different rice cultivars

\begin{tabular}{lll}
\hline Source of Variations & df & Amylose \\
\hline Rice Varieties (V) & 4 & $6.92 * *$ \\
Rice Fractions (F) & 1 & $23.9 * *$ \\
V*F & 4 & $0.30 * *$ \\
Error & 20 & 0.001 \\
Total & 29 & \\
\hline Note: $* *=$ Highly Significant at $\mathrm{P}<0.05$ & &
\end{tabular}


Table 6. Effect of cultivar on amylose (\%) of brown and white rice fractions of different rice cultivars

\begin{tabular}{lll}
\hline Variety & Fraction & Amylose \\
\hline IRRI-9 & Brown & $27.07 \pm 0.01$ \\
IRRI-6 & White & $28.25 \pm 0.01$ \\
& Brown & $27.55 \pm 0.01$ \\
KSK-434 & White & $29.78 \pm 0.05$ \\
& Brown & $26.48 \pm 0.01$ \\
KSK-133 & White & $27.96 \pm 0.05$ \\
& Brown & $26.80 \pm 0.10$ \\
Shadab & White & $28.98 \pm 0.01$ \\
& Brown & $29.03 \pm 0.05$ \\
\hline
\end{tabular}

Note: Values are presented as Means \pm SD; $n=3$ 